\title{
PENGEMBANGAN MEDIA PEMBELAJARAN AKUNTANSI SMK BERBASIS ANIMASI INTERAKTIF PADA MATERI ASET TETAP BERWUJUD
}

\author{
Anissatul Khamidah dan Susanti \\ Prodi Pendidikan Akuntansi Jurusan Pendidikan Ekonomi FE UNESA \\ Afnie_beloved@yahoo.co.id \\ susanti_otto@yahoo.com
}

\begin{abstract}
ABSTRAK
Tujuan penelitian ini adalah mengembangkan media pembelajaran akuntansi SMK berbasis animasi interaktif dan mengetahui kelayakan media animasi interaktif sebagai media alternatif dalam proses pembelajaran akuntansi kelas XI akuntansi di SMK pada materi pengelolaan kartu aset tetap. Jenis penelitian ini adalah penelitian pengembangan dengan model Thiagarajan yaitu model 4D (four D Models) yang terdiri dari tahap pendefinisian (Define), tahap pendesainan (Design), tahap pengembangan (Develop), dan tahap penyebaran (Disseminate). Penelitian ini hanya sampai pada tahap pengembangan, tahap penyebaran tidak dilakukan karena keterbatasan waktu dan dana.Validasi media dilakukan oleh tiga subyek yaitu ahli materi, ahli media dan pengguna yaitu siswa. Simpulan penelitian media pembelajaran akuntansi SMK berbasis animasi interaktif yang dikembangkan ini hanya sampai pada tahap pengembangan (develop) dan tingkatkelayakannyayaitu sebesar $94,55 \%$ dengan kategori sangat layak. Saran penelitian ini adalah media animasi interaktif ini cocok diterapkan dengan menggunakan model pembelajaran langsung;penggunaan media animasi interaktif ini diperlukan beberapa spesifikasi komputer; perlu dilakukan penelitian lebih lanjut pada tahap penyebaran (dessiminate); perlu adanya kelayakan sampai hasil belajar; dan perlunya perluasan penerapan pada materi lain.
\end{abstract}

Kata Kunci: media pembelajaran, animasi interaktif, kelayakan

\section{PENDAHULUAN}

\section{Latar Belakang Masalah}

Mata diklat akuntansi pada Sekolah Menengah Kejuruan (SMK) merupakan salah satu mata pelajaran produktif untuk program keahlian akuntansi artinya mata pelajaran yang wajib dipelajari karena sangat berhubungan dengan kompetensi dan keahlian siswa dalam bidang akuntansi. Salah satu tujuan pembelajaran akuntansi di SMK adalah agar siswa dapat menggunakan konsep atau rumus akuntansi yang ada dalam pembelajaran lebih lanjut. Fakta di lapangan berdasarkan hasil wawancara dengan siswa kelas XI Ak-1 di SMK Negeri 10 Surabaya, tidak semua siswa SMK mampu menerapkan konsep-konsep akuntansi yang ada dalam pembelajaran lebih lanjut. Hal ini dikarenakan sering kali siswa mengalami kesulitan dalam pemahaman konsep akuntansi. Penyebab dari kesulitan pemahaman konsep akuntansi tersebut antara lain: Pertama, bahwa kebanyakan dari konsep akuntansi adalah bersifat abstrak 
sehingga memerlukan pemahaman konsep sebelum memahami rumus, tetapi pada kenyataannya pembelajaran yang dilakukan lebih fokus pada penyelesaian soal. Kedua, konsep akuntansi terjadi atau dapat dilihat langsung di kehidupan sehari-hari tetapi banyak siswa yang tidak mengetahui konsep dari akuntansi yang ada di lingkungannya. Salah satunya adalah pada materi pengelolaan kartu aset tetap misalnya siswa dituntut untuk mampu mengidentifikasi depresiasi dan akumulasi depresiasi aset tetap, namun siswa tidak pernah diberikan visualisai dari konsepkonsep depresiasi aset tetap, siswa hanya sekedar mengetahui teori tanpa adanya pemahaman konsep yang mendalam sehingga siswa tidak mengetahui aplikasi dari konsep akuntansi yang terjadi dalam kehidupan sehari-hari. Upaya untuk mengatasi kesulitan dalam pemahaman konsep akuntansi tersebut yaitu dengan menggunakan media pembelajaran dalam proses belajar mengajar.

Pentingnya media pengajaran dikemukakan oleh Sudjana (2002), bahwa dengan penggunaan media pengajaran dapat mempertinggi proses belajar mengajar siswa dalam pengajaran yang pada gilirannya diharapkan dapat mempertinggi hasil belajar yang dicapainya. Penggunaan media pengajaran pada saat terjadinya proses belajar mengajar dalam kelas diharapkan dapat mempertinggi minat dan perhatian siswa dalam mengikuti proses belajar mengajar yang sedang berlangsung. Menurut Arsyad (2007:31) media berbasis komputer merupakan cara menghasilkan atau menyampaikan materi dengan menggunakan sumber-sumber yang berbasis mikroprosesor. Salah satu bentuk penyajian tampilan visual dengan bantuan komputer adalah media animasi melalui program macromedia flash professional 8. Media animasi termasuk jenis media visual audio, karena terdapat gerakan gambar dan suara. Media animasi ini dapat digunakan sebagai alternatif media pembelajaran berbasis komputer selain power point. Dalam penelitian ini, peneliti melakukan pengembangan media animasi. Alasan dipilihnya media animasi sebagai media pembelajaran Akuntansi yang dikembangkan adalah: (1) Media animasi memiliki kemampuan untuk dapat memaparkan sesuatu yang kompleks atau sulit untuk dijelaskan dengan hanya kata-kata saja, gambar-gambar animasi yang ada dapat memperjelas materi yang belum dipahami, (2) Media animasi dapat menjanjikan suatu visual yang lebih dinamik serta menarik, (3) Media animasi membuat siswa lebih mengingat materi lebih lama (4)Media animasi dapat membuat materi pelajaran yang abstrak menjadi lebih konkrit serta menambah kesan realisme, dan (5) Media Animasi cocok untuk menjelaskan materi-materi pelajaran yang secara langsung sulit dihadirkan dikelas atau disampaikan dalam bentuk buku. 
Implementasi pada animasi dapat dikerjakan secara interaktif maupun non interaktif. Dibandingkan animasi non interaktif, animasi interaktif memberikan tampilan yang lebih menarik dan dinamis. Pada animasi interaktif, pergerakan objek mengikuti perintah yang diberikan oleh pemakai lewat perangkat interaktif. Sedangkan animasi non interaktif, pergerakan objek hanya dikendalikan dari prosedur yang ada di dalam sebuah program.

Ada beberapa hasil penelitian terkait pengembangan media animasi interaktif. Media pembelajaran dengan menggunakan animasi sangat bermanfaat dalam proses pembelajaran terutama pembelajaran akuntansi. Hal ini sangat bermanfaat untuk meningkatkan hasil belajar, aktivitas belajar, minat dan motivasi siswa dan guru. Oleh karena itu media pembelajaran animasi interaktif perlu dikembangkan lebih lanjut. Aula (2011) mengembangkan media pembelajaran interaktif pada materi jurnal penyesuaian. Hasil pengembangan Aula (2011) memenuhi 36 kriteria layak untuk digunakan. Saputro (2011) juga mengembangkan media pembelajaran interaktif berbasis komputer pada materi pokok termokimia bilingual kelas XI IPS di Rintisan SMA Bertaraf Internasional. Hasil pengembangannya sangat layak digunakan sebagai media pembelajaran interaktif.

Berdasarkan uraian di atas, maka perlu diadakan penelitian tentang pengembangan media pembelajaran akuntansi berbasis animasi interaktif untuk Sekolah Menengah Kejuruan dengan judul penelitian: "Pengembangan Media Pembelajaran Akuntansi SMK Berbasis Animasi Interaktif pada Materi Aset Tetap Berwujud".

\section{Rumusan Masalah}

Berdasarkan permasalahan tersebut, maka dirumuskan suatu pertanyaan:

1. Bagaimana mengembangkan media pembelajaran Akuntansi SMK berbasis animasi interaktif pada materi pengelolaan kartu aset tetap ?

2. Bagaimana kelayakan media pembelajaran akuntansi SMK berbasis digunakan sebagai media alternatif dalam proses pembelajaran akuntansi kelas XI akuntansi di SMK pada materi pengelolaan kartu aset tetap ?

\section{Tujuan Pengembangan}

1. Untuk mengembangkan media pembelajaran Akuntansi SMK berbasis animasi interaktif pada materi pengelolaan kartu aset tetap.

2. Untuk mengetahui kelayakan media animasi interaktif sebagai media alternatif dalam proses pembelajaran akuntansi kelas XI akuntansi di SMK pada materi pengelolaan kartu aset tetap. 
KAJIAN PUSTAKA

\section{Media Pembelajaran Animasi Interaktif}

Menurut Miarso dalam Susilana \& Riyana, (2007:6), media adalah segala sesuatu yang dapat digunakan untuk menyalurkan pesan yang dapat merangsang pikiran, perasaan, perhatian, dan kemauan siswa untuk belajar media. Gagne mengartikan media sebagai jenis komponen dalam lingkungan siswa yang dapat merangsang mereka untuk belajar. Briggs mengartikan media sebagai alat untuk memberikan perangsang bagi siswa agar terjadi proses belajar (Arsyad, 2007:4). Sedangkan pengertian pembelajaran adalah usaha sadar dari seorang guru untuk membelajarkan siswanya (mengarahkan interaksi siswa dengan sumber belajar lainnya) dalam rangka mencapai tujuan yang yang diharapkan (Trianto, 2009:17). Berdasarkan definisi dari media dan pembelajaran, maka dapat disimpulkan bahwa media pembelajaran adalah media yang digunakan dalam pembelajaran, yaitu meliputi alat bantu guru dalam mengajar serta sarana pembawa pesan dari sumber belajar ke penerima pesan belajar (siswa).

Menurut Wikipedia (2009), animasi atau lebih akrab disebut dengan film animasi adalah film yang merupakan hasil dari pengolahan gambar tangan sehingga menjadi gambar yang bergerak, dengan bantuan computer dan grafika computer, pembuatan film animasi menjadi sangat mudah dan cepat. Sedangkan pengertian interaktif adalah bersifat saling melakukan aksi; antar-hubungan; saling aktif. Karakterisitik dalam media interaktif menurut Susilana \& Riyana (2007:22) adalah bahwa siswa tidak hanya memperhatikan media atau obyek saja, melainkan juga dituntut untuk berinteraksi selama mengikuti pembelajaran.Berdasarkan definisi media animasi dan interaktif, maka dapat disimpulkan bahwa media animasi interaktif adalah alat perantara yang dirancang dengan pemanfaatan komputer menggunakan unsur seperti suara (audio), gambar (visual) dan teks untuk menyampaikan suatu pesan.

\section{Pengembangan Media Pembelajaran}

Model pengembangan media pembelajaran seperti yang disarankan oleh Thiagarajan, Semmel, dan Semsel (1974 dalam Trianto, 2009:189) adalah Model 4-D (four $D$ Models). Model ini terdiri dan 4 tahap pengembangan yaitu:

1. Tahap Pendefinisian (Define)

Tujuan tahap ini adalah menetapkan dan mendefinisikan syarat-syarat pembelajaran. Tahap ini dilakukan dengan melakukan analisis tujua dalam batasan materi pelajaran yang akan dikembangkan perangkatnya. Ada lima langkah pokok 
di dalam tahap ini, yaitu analisis ujung depan, analisis siswa, analisis tugas, analisis konsep, dan perumusan tujuan pembelajaran.

2. Tahap Perancangan (Design)

Pada tahap ini dilakukan perancangan prototipe perangkat pembelajaran. Dalam tahap ini dilakukan penyusunan tes. Langkah ini merupakan jembatan yang menghubungkan tahap pendefinisian dengan perancangan. Disamping itu di dalam tahap ini juga dilakukan pemilihan media yang sesuai tujuan, untuk menyampaikan materi pelajaran. Termasuk pula dalam tahap ini adalah pemilihan format. Dalam pemilihan format dapat dilakukan dengan mengkaji format-format perangkat yang sudah ada dan yang sudah dikembangkan di negara yang lebih maju. Hasil tahap ini biasanya berupa rancangan awal perangkat.

3. Tahap Pengembangan (Develop)

Tahap pengembangan ini bertujuan untuk menghasilkan perangkat pembelajaran yang sudah direvisi berdasarkan masukan para pakar. Validasi perangkat oleh pakar diikuti dengan revisi kemudian simulasi, yaitu kegiatan mengoperasionalkan rencana pelajaran. Kegiatan ini ditujukan untuk mengecek keterlaksanaan perangkat, kecocokan waktu, kerja alat dan sebagainya. Terakhir uji coba terbatas dengan siswa yang sesungguhnya.

4. Tahap Penyebaran (Disseminate)

Tahap ini merupakan tahapan penggunaan perangkat yang telah dikembangkan ada skala yang lebih luas misalnya di kelas lain, di sekolah lain, oleh guru yang lain dan sebagainya. Tujuan tahap ini juga untuk menguji efektivitas penggunaan perangkat di dalam proses belajar mengajar.

\section{Kelayakan Media Pembelajaran}

Walker \& Hess 1984:206 (dalam Arsyad, 2007:175) memberikan kriteria dalam mereviu perangkat lunak media pembelajaran yang berdasarkan kepada kualitas.

1. Kualitas isi dan tujuan

Kualitas isi dan tujuan terdiri dari a) ketepatan, b) kepentingan, c) kelengkapan, d) keseimbangan, e) minat/perhatian, f) keadilan dan g) kesesuaian dengan situasi siswa.

2. Kualitas instruksional

Kualitas instruksional terdiri dari a) memberikan kesempatan belajar, b) memberikan bantuan untuk belajar, c) kualitas memotivasi, d) fleksibelitas instruksionalnya, e) hubungan dengan program pembelajaran lainnya, f) kualitas 
sosial interaksi instruksionalnya, g) kualitas tes dan penilaiannya, h) dapat memberi dampak bagi siswa dan i) dapat membawa dampak bagi guru dan pembelajarannya.

3. Kualitas teknis

Kualitas teknis terdiri dari a) keterbacaan, b) mudah digunakan, c) kualitas tampilan/ tayangan, d) kualitas penanganan programnya dan e) kualitas pendokumentasiannya.

\section{Materi Aset Tetap}

Materi aset tetap secara nasional dirancang sama pada kurikulum SMK. Adapun pokok bahasan materi aset tetap SMK Kelas XI Akuntansi adalah sebagai berikut: a). Menyiapkan pengelolaan kartu aktiva tetap, b). Mengidentifikasi data mutasi aktiva tetap, c). Mengidentifikasi penyusutan dan akumulasi penyusutan aktiva tetap, d). Membukukan mutasi aktiva tetap ke kartu aktiva tetap, e). Membukukan penyusutan dan akumulasi penyusutan ke kartu aktiva tetap, f). Melakukan inventarisasi fisik aktiva tetap secara periodik, dan g). Membuat laporan aktiva tetap.

Pencatatan aset tetap memerlukan dokumen-dokumen transaksi yang diperlukan. Adapun dokumen-dokumen transaksi yang diperlukan adalah faktur dari pabrikan atau pihak lainnya sebagai bukti transaksi pembelian, bukti setoran pajak pertambahan nilai (PPN), bukti pengeluaran kas, dan bukti memorial. Pencatatan asset terdiri dari pencatatan transaksi pembelian tunai, pencatatan transaksi pembelian secara kredit, pencatatan transaksi pertukaran dengan aktiva non kas dan pencatatan aset tetap sumbangan dari pihak lain

Kegiatan pengelolaan aktiva tetap harus menghasilkan data mengenai aset tetap yang sewaktu-waktu atau secara periodik dapat dilaporkan kepada manajemen.Jenis-jenis laporan mengenai aset tetap antara lain: a) laporan aset tetap dalam kondisi rusak, b) laporan aset tetap yang sedang diperbaiki/diservis, c) laporan aset tetap yang digunakan dan d) laporan penyusutan aset tetap.

\section{Penelitian Terdahulu yang Relevan}

Tabel 1.1.

Penelitian Terdahulu

\begin{tabular}{|c|c|c|c|}
\hline No & Nama Peneliti & Judul & Hasil Penelitian \\
\hline 1 & Khussotul Aula & $\begin{array}{lr}\text { Pengembangan } & \text { Media } \\
\text { Pembelajaran } & \text { Interaktif } \\
\text { Berbasis Komputer } & \text { Pada Sub } \\
\text { Pokok Bahasan r Jurnal } \\
\text { Penyesuaian Perusahaan Jasa. }\end{array}$ & $\begin{array}{l}\text { Bahwa media media } \\
\text { pembelajaran interaktif komputer } \\
\text { yang dikembangkan memenuhi } 6 \\
\text { kriteria layak untuk digunakan. }\end{array}$ \\
\hline
\end{tabular}




\begin{tabular}{|c|c|c|c|}
\hline No & Nama Peneliti & Judul & Hasil Penelitian \\
\hline 2 & Irfan Saputro & $\begin{array}{l}\text { Pengembangan media } \\
\text { pembelajaran interaktif berbasis } \\
\text { komputer pada materi pokok } \\
\text { termokimia bilingual kelas XI } \\
\text { IPS di Rintisan SMA Bertaraf } \\
\text { Internasional. }\end{array}$ & $\begin{array}{l}\text { Bahwa media interaktif berbasis } \\
\text { komputer pada materi pokok } \\
\text { termokimia bilingual sangat layak } \\
\text { digunakan sebagai media } \\
\text { pembelajaran di Rintisan SMA } \\
\text { Bertaraf Internasional. }\end{array}$ \\
\hline 3 & Melani Agustina & $\begin{array}{l}\text { Pengembangan Media Interaktif } \\
\text { Berbasis Komputer Pada Materi } \\
\text { Pokok Asam Dan Basa }\end{array}$ & $\begin{array}{l}\text { Bahwa indikator kelayakan media } \\
\text { telah tercapai dan media interaktif } \\
\text { berbasis komputer yang } \\
\text { dikembangkan pada materi pokok } \\
\text { Asam dan Basa telah layak untuk } \\
\text { digunakan sebagai media } \\
\text { pembelajaran. }\end{array}$ \\
\hline
\end{tabular}

\section{METODE PENGEMBANGAN}

Model pengembangan yang digunakan yaitu model pengembangan menurut Thiagarajan yaitu model 4D (four D Models) yang terdiri dari: tahap pendefinisian (Define), tahap pendesainan (Design), tahap pengembangan (Develop), dan tahap penyebaran (Disseminate). Penelitian pengembangan ini hanya sampai pada tahap pengembangan(Develop) sedangkan tahappenyebaran (Disseminate) tidak dilakukan karena media ini hanya digunakan pada lingkup sekolah tertentu dan peneliti hanya sebatas mengembangkan media animasi interaktif saja. Adapun prosedur pengembangan adalah sebagai berikut:

a. Tahap pendefinisian. Tahap ini dilakukan dengan melakukan analisis tujuan dalam batasan materi pelajaran yang akan dikembangkan. Ada 4 langkah pokok di dalam tahap ini, yaitu : 1) analisis ujung depan, 2) analisis siswa, 3) analisis tugas, dan 4) analisis konsep.

b. Tahap Perancangan. Kegiatan utama pada tahap ini meliputi: a). Merumuskan konsep yang akan disajikan dalam media pembelajaran Akuntansi SMK berbasis animasi interaktif, dan b). Memasukkan konsep materi pokok dan latihan-latihan soal dengan menggunakan program Macromedia Flash.

c. Tahap pengembangan. Tujuan dari tahap ini adalah untuk menvalidkan media pembelajaran akuntansi SMK berbasis animasi interaktif pada materi pengelolaan kartu aset tetap. Melalui tahap ini media akan mendapatkan revisi bergantung pada pendapat ahli media dan ahli materi.

\section{Uji Coba Produk}

Dalam pelaksanaan uji coba tersebut akan dilakukan lima tahap yaitu (a). desain uji coba, (b). subjek uji coba, (c). jenis data, (d). instrumen pengumpulan data dan (e). teknik analisis data.Pada tahap desain uji coba media pembelajaran akuntansi 
berbasis animasi interaktif, pengembang membuat suatu rancangan kegiatan yang akan dilakukan selama proses pengembangan sesuai prosedur penelitian model 4-D yang telah dirancang.Dalam pengembangan ini, subjek uji coba pengembangan media animasi interaktif ini terdiri dari ahli media selaku orang yang berkompetensi dalam bidang media flash (satu orang dosen), Ahli materi selaku orang yang berkompetensi dalam bidang akuntansi (dua orang dosen dan satu guru SMK Akuntansi) dan siswa kelas XI Akuntansi di SMK Negeri 10 Surabaya yang diambil 20 siswa untuk uji coba terbatas.

Jenis data yang diperoleh dalam pengembangan ini adalah data kualitatif (dari hasil telaah media berupa angket telaah oleh ahli materi dan ahli media) dan kuantitatif (didapatkan dari hasil validasi (ahli media dan ahli materi) dan pendapat siswa yang kemudian dianalisis dengan teknik persentase).

Adapun instrumen pengumpulan data yang digunakan dalam penelitian ini adalah lembar angket yang terdiri dari angket terbuka dan tertutup. Angket terbuka terdiri dari angket telaah ahli media dan angket telaah ahli materi sedangkan angket tertutup terdiri dari angket validasi Ahli Media, angket Validasi Ahli Materi dan angket pendapat siswa.

Teknik analisis data yang digunakan adalah menggunakan angket. Angket validasi oleh ahli media dan ahli materi dianalisis secara deskriptif kuantitatif. Prosentase tersebut diperoleh dengan berdasarkan perhitungan skor menurut Skala Likert yang diadaptasi dari Riduwan (2010) dengan kriteria: Sangat baik skor 4, baik skor 3 , sedang skor 2 , tidak baik skor 1 dan sangat tidak baik dengan skor 0 . Sedangkan angket pendapat siswa dianalisis berdasarkan perhitungan skala Guttman pada table 1.2 berikut:

Tabel 1.2

\section{Kriteria Skala Guttman}

\begin{tabular}{|c|c|}
\hline Jawaban & Nilai/Skor \\
\hline $\mathrm{Ya}(\mathrm{Y})$ & 1 \\
\hline Tidak $(\mathrm{T})$ & 0 \\
\hline
\end{tabular}

(Diadaptasi dari Riduwan, 2010)

Data hasil angket dianalisis dengan cara :

$$
K=\frac{F}{N x I \times R} \times 100 \%
$$

$\begin{array}{lll}\text { Keterangan: } & \mathrm{K} & =\text { Persentase kriteria kelayakan } \\ \mathrm{F} & =\text { Jumlah keseluruhan jawaban responden } \\ \mathrm{N} & =\text { Skor tertinggi dalam angket } \\ \mathrm{I} & =\text { Jumlah pertanyaan dalam angket } \\ \mathrm{R} & =\text { Jumlah responden }\end{array}$


Untuk kesimpulan tentang kelayakan media menggunakan skala likert dengan kriteria: sangat tidak layak (0\%-20\%), tidak layak (21\%-40\%), cukup layak (41\%-60\%), layak (61-80\%) dan sangat layak (81\%-100\%). Oleh karena itu dalam penelitian ini, media animasi interaktif yang dikembangkan dapat dikatakan layak apabila rata-rata dari semua aspek dalam angket mendapatkan persentase sebesar lebih dari $61 \%$ sehingga interprestasi dari media sangat kuat atau kuat.

\section{HASIL DAN PEMBAHASAN}

\section{Hasil Pengembangan}

Pengembangan Media Pembelajaran Akuntansi SMK Berbasis Animasi Interaktif Pada Materi Pengelolaan Kartu Aset Tetap.

Berikut ini adalah hasil tampilan media pembelajaran akuntansi berbasis animasi interaktif yang telah dikembangkan sebelum dan sesudah revisi dari ahli media dan ahli materi:

\section{Bagan 1.1}

Hasil Pengembangan Media Pembelajaran Berbasis Animasi Interaktif Pada Materi Aset Tetap Sebelum dan Sesudah Revisi dari Ahli Media

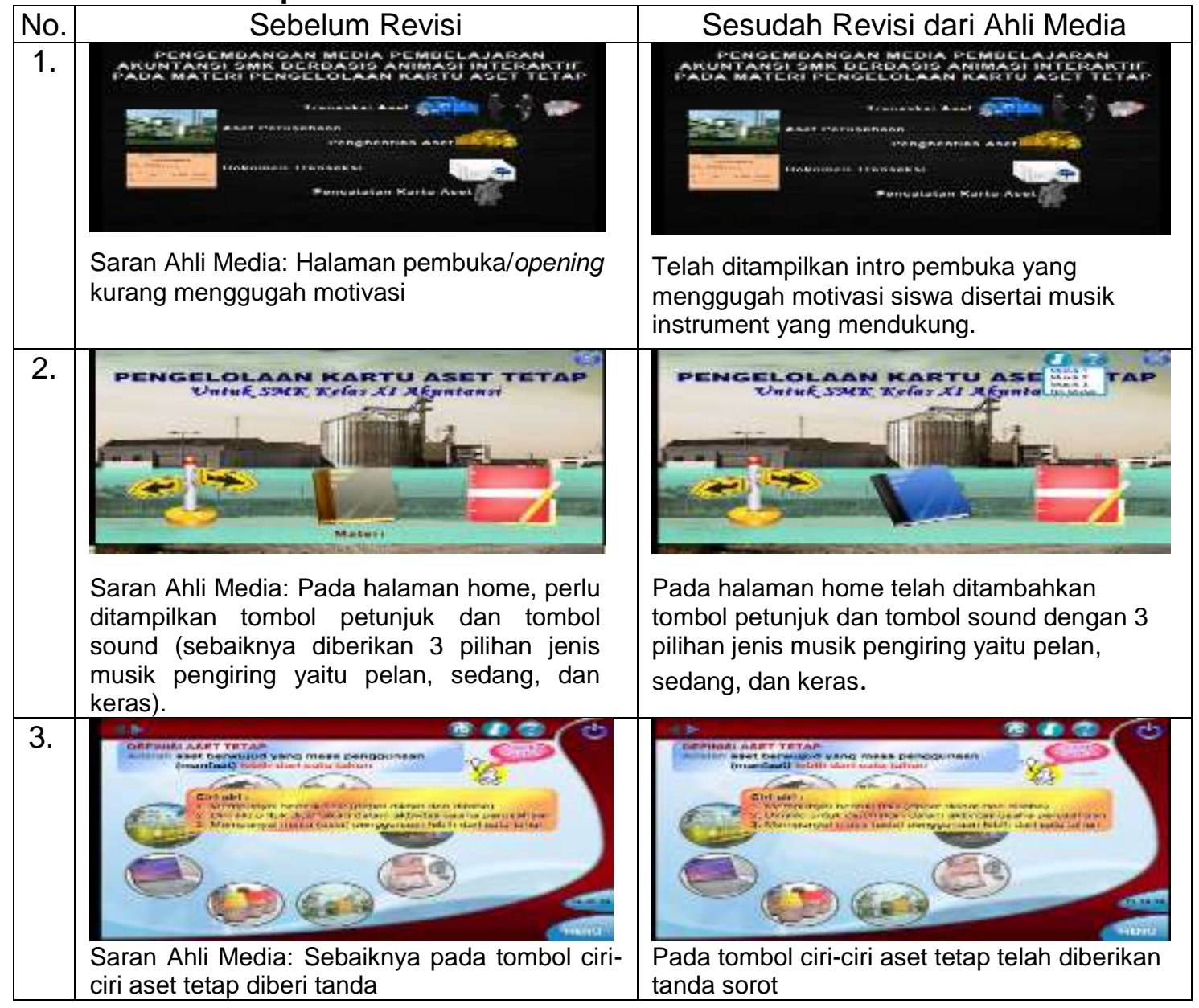




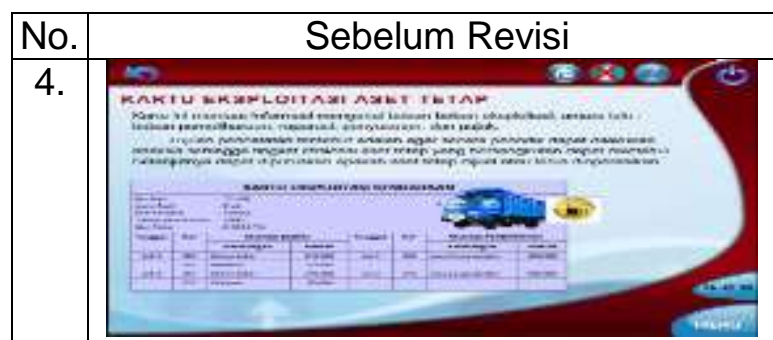

Saran Ahli Media: Sebaiknya animasi menuju pada tulisan gambar yang bersangkutan dan menetap

5.

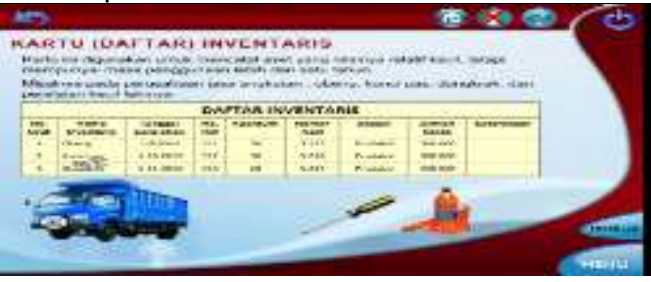

Saran Ahli Media: Sebaiknya animasi tidak terlalu cepat dan menetap pada tulisan gambar yang bersangkutan.

6.

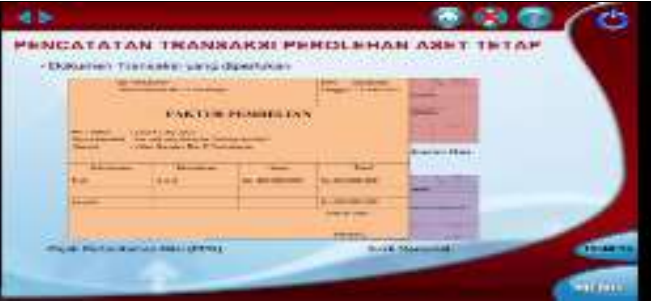

Saran Ahli Media: Sebaiknya areal sentuh pencatatan transaksi diperluas atau diganti klik.

7.

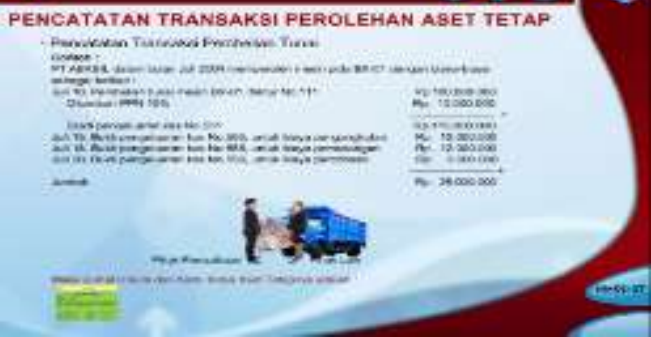

Saran Ahli Media: Sebaiknya areal sentuh pencatatan transaksi diperluas atau diganti klik.

8.

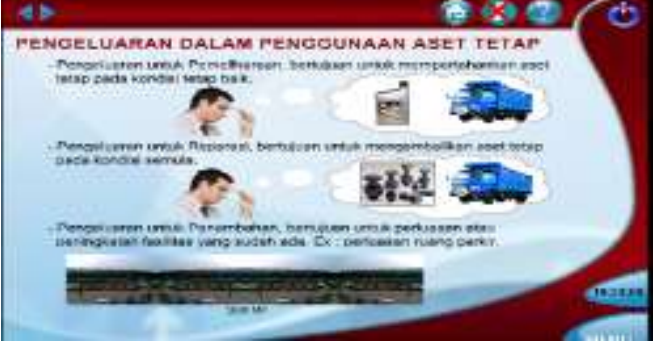

Saran Ahli Media: Untuk kalimat penting, sebaiknya ditebali atau diberikan warna.

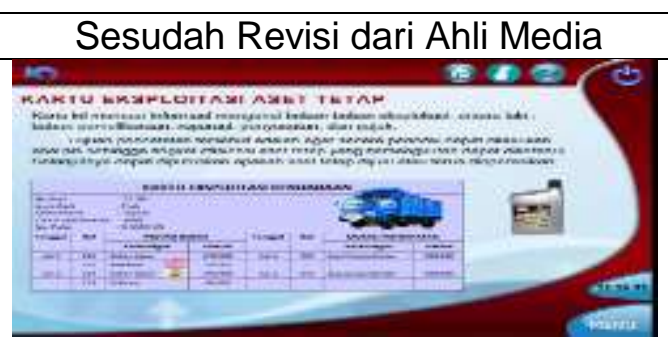

Animasi telah ditujukan pada tulisan gambar yang bersangkutan dan menetap

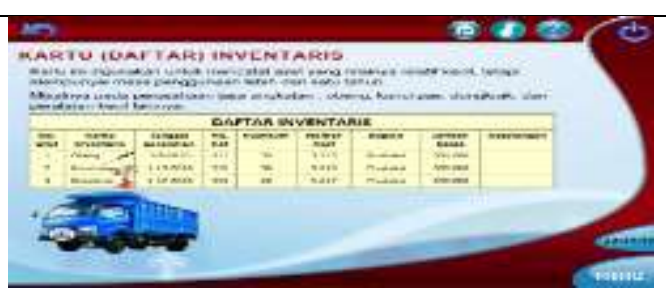

Animasi telah dibuat pelan dan menetap pada tulisan gambar yang bersangkutan

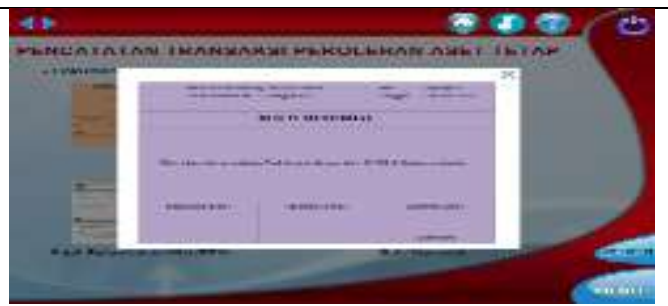

Sorot gambar telah diganti dengan klik

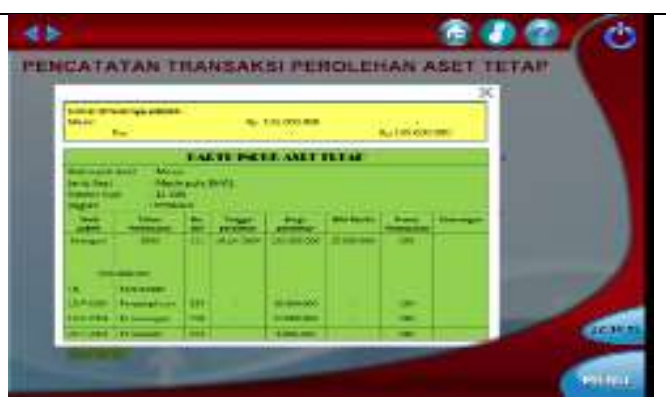

Sorot gambar telah diganti dengan klik

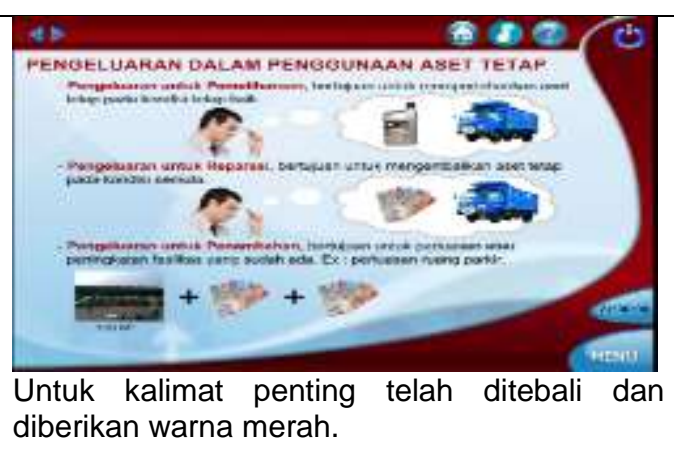




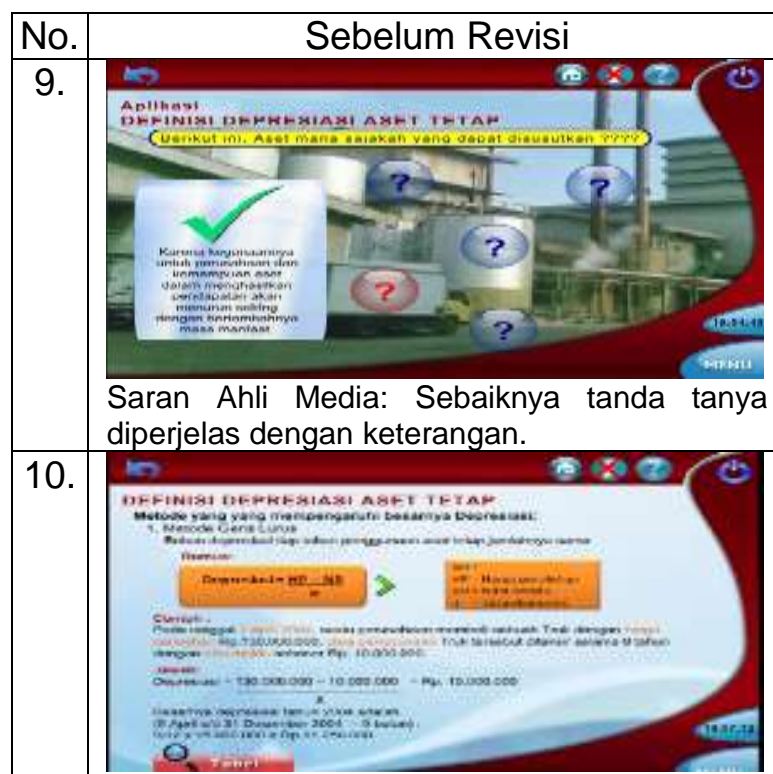

Saran Ahli Media: Penulisan rumus salah, sebaiknya dibenarkan sesuai dengan aturan penulisan.

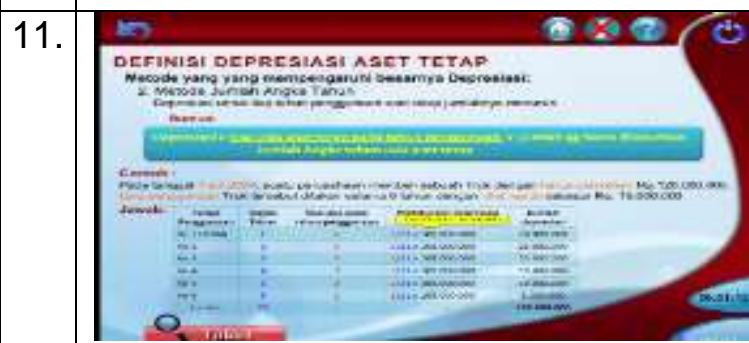

Saran Ahli Media: Penulisan rumus salah, sebaiknya dibenarkan sesuai dengan aturan penulisan.

12.

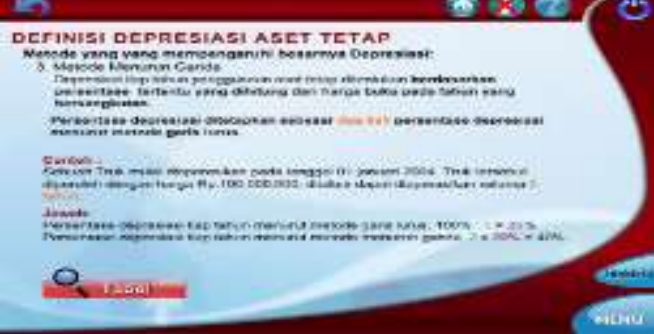

Saran Ahli Media: Sebaiknya ukuran teks diperbesar, supaya kata 5 tahun tidak berpisah.

13.

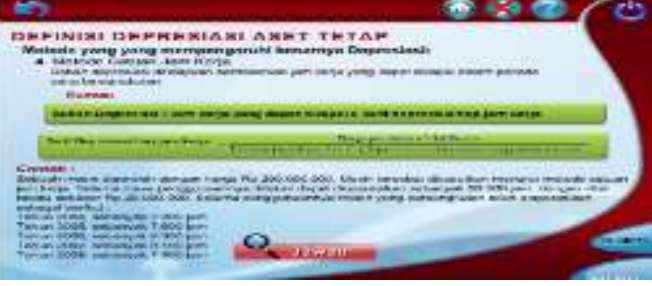

Saran Ahli Media: Penulisan rumus salah, sebaiknya dibenarkan sesuai dengan aturan penulisan.

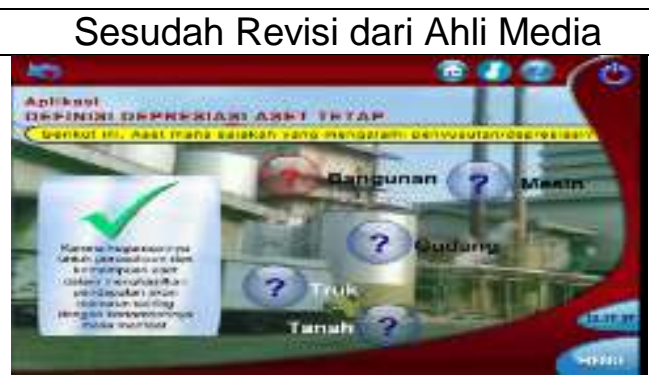

Tanda tanya telah diperjelas dengan keterangan.

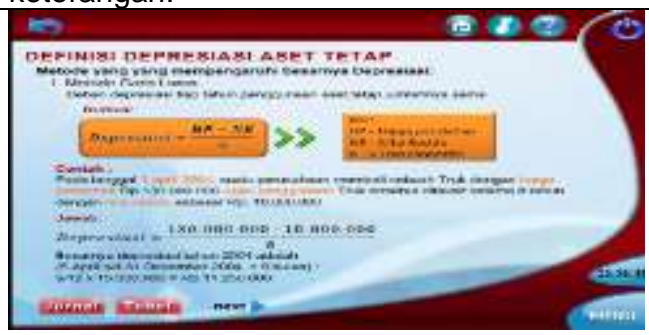

Penulisan rumus telah dibenarkan.

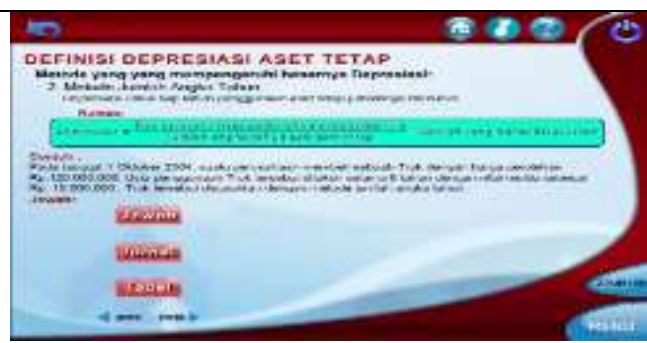

Penulisan rumus telah dibenarkan.

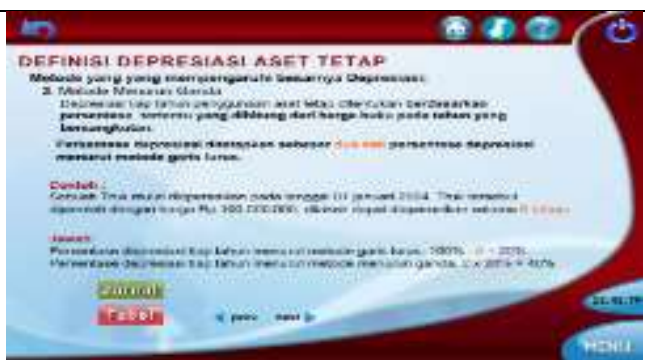

Ukuran teks telah diperbesar.

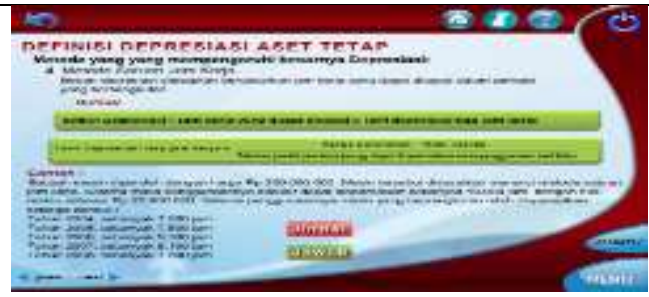

Penulisan rumus telah dibenarkan. 


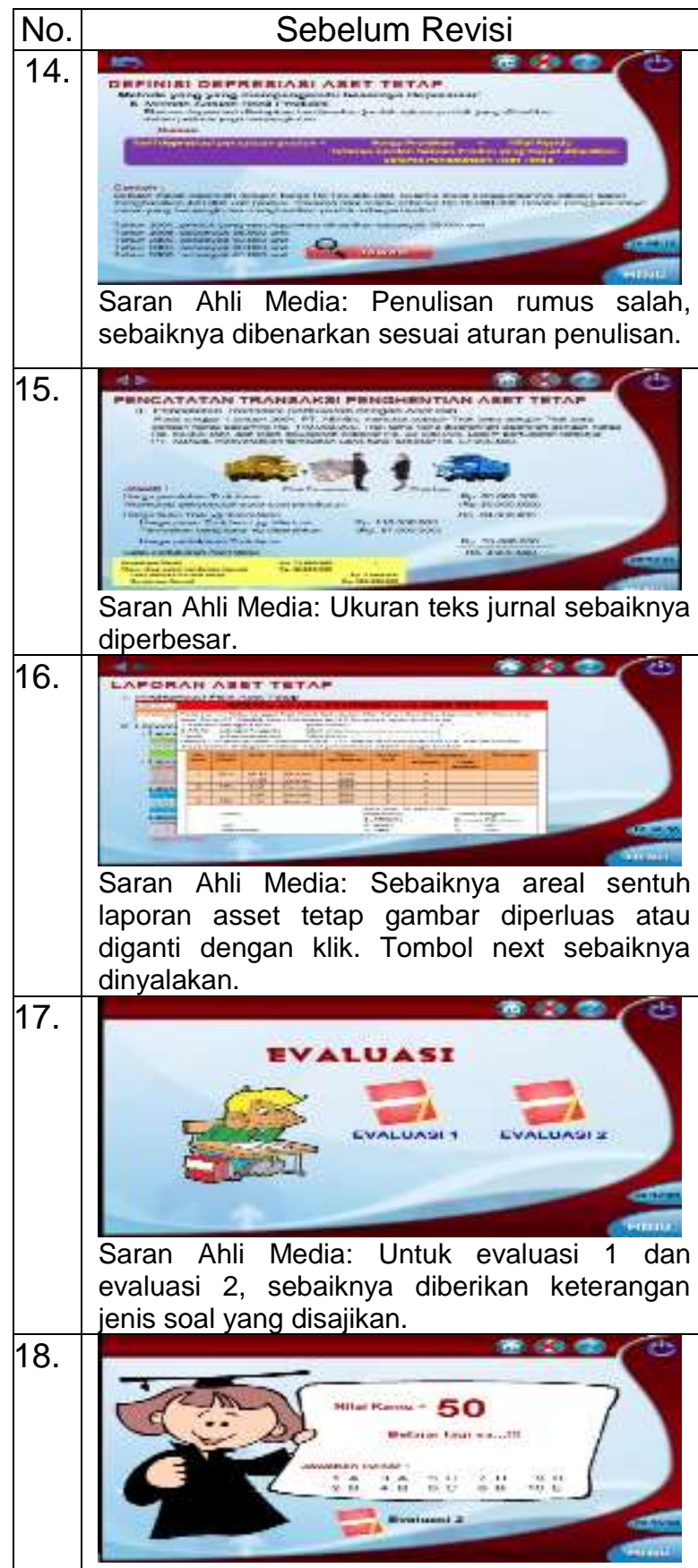

Saran Ahli Media: Kalau bisa, jawaban yang telah dijawab siswa ditampilkan di atas jawaban yang benar dan diberikan tanda warna merah untuk jawaban siswa yang salah.

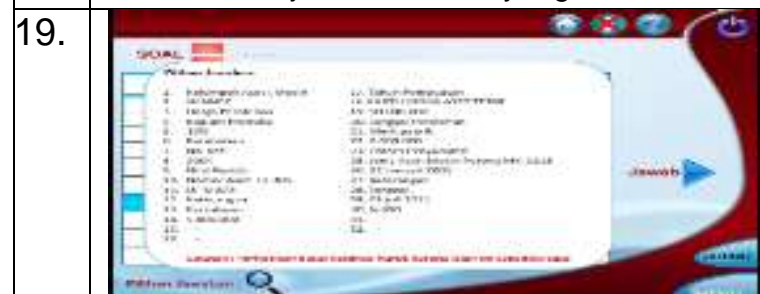

Saran Ahli Media: Untuk pilihan jawaban, sebaiknya dibuat fleksibel agar siswa tidak mengalami kesulitan melihat pilihan jawaban.

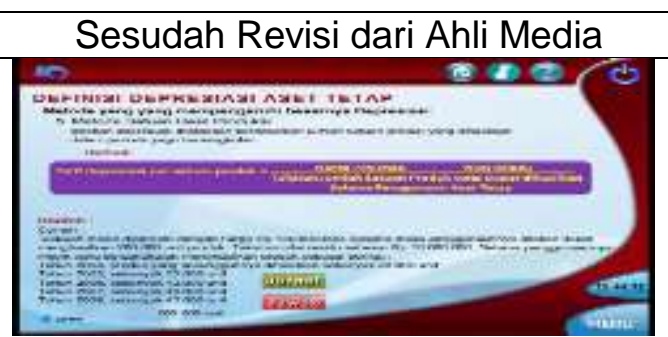

Penulisan rumus telah dibenarkan

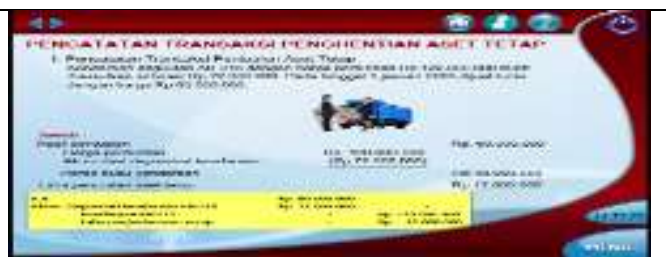

Ukuran teks dalam jurnal telah diperbesar.

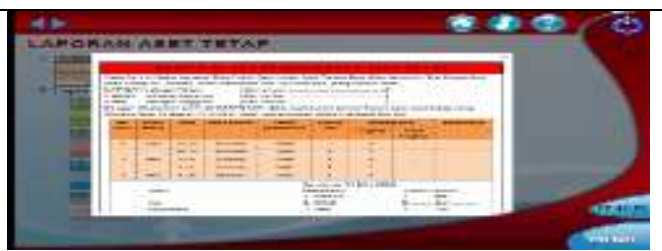

Sorot gambar telah diganti dengan klik. Tombol next telah dinyalakan

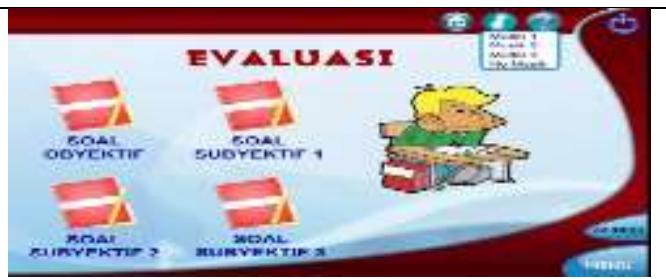

Telah diberikan keterangan jenis soal pada evaluasi 1 dan evaluasi 2 .

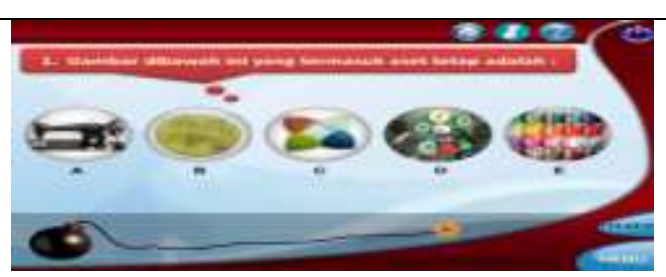

Telah ditampilkan balikan secara langsung atas jawaban benar atau salah dari setiap pertanyaan.

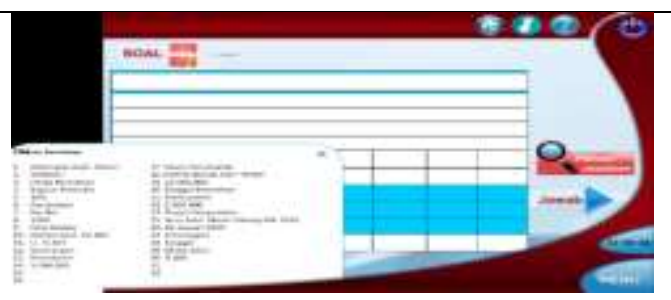

Pilihan jawaban telah dibuat fleksibel yaitu bisa dipindah-pindah. 


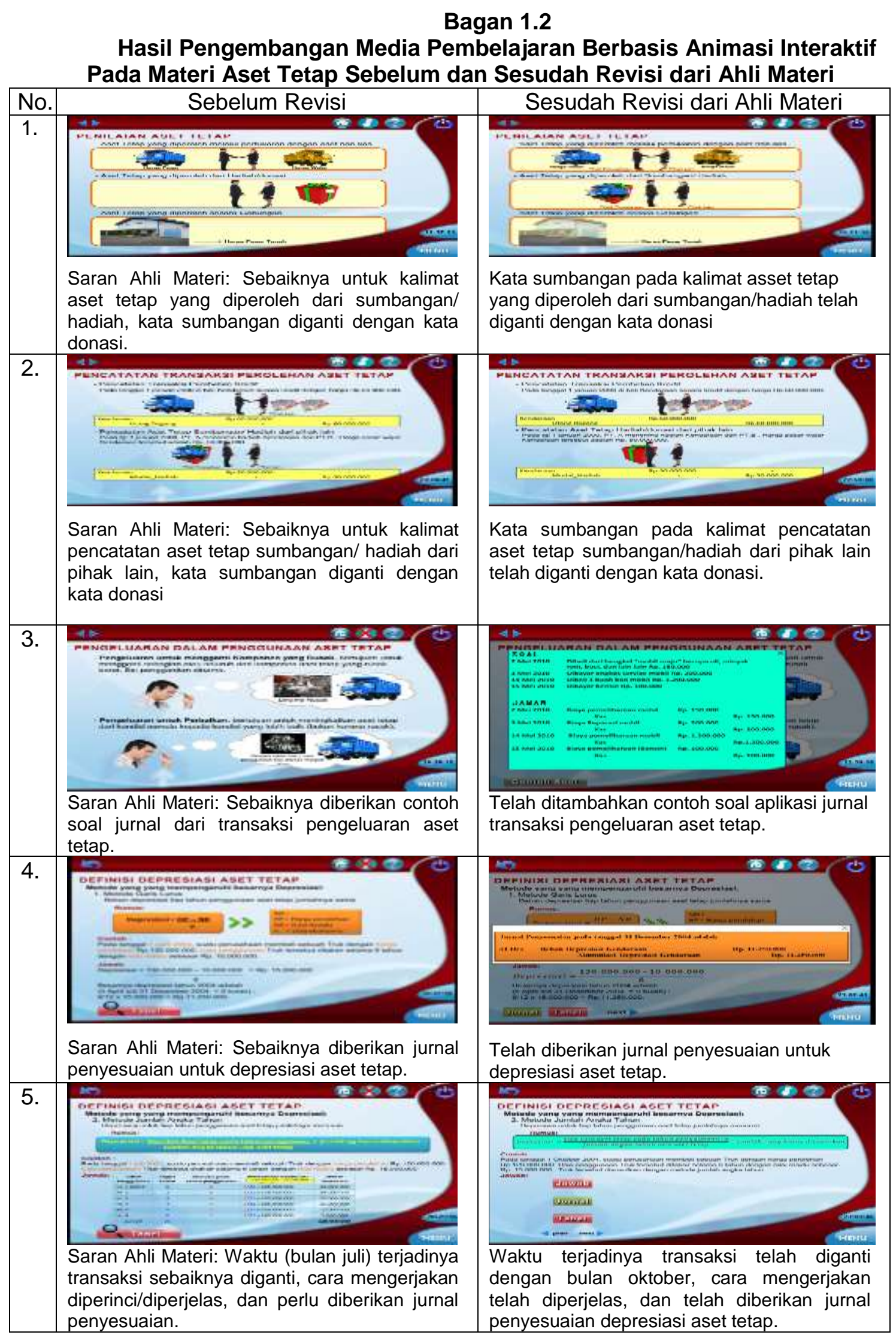




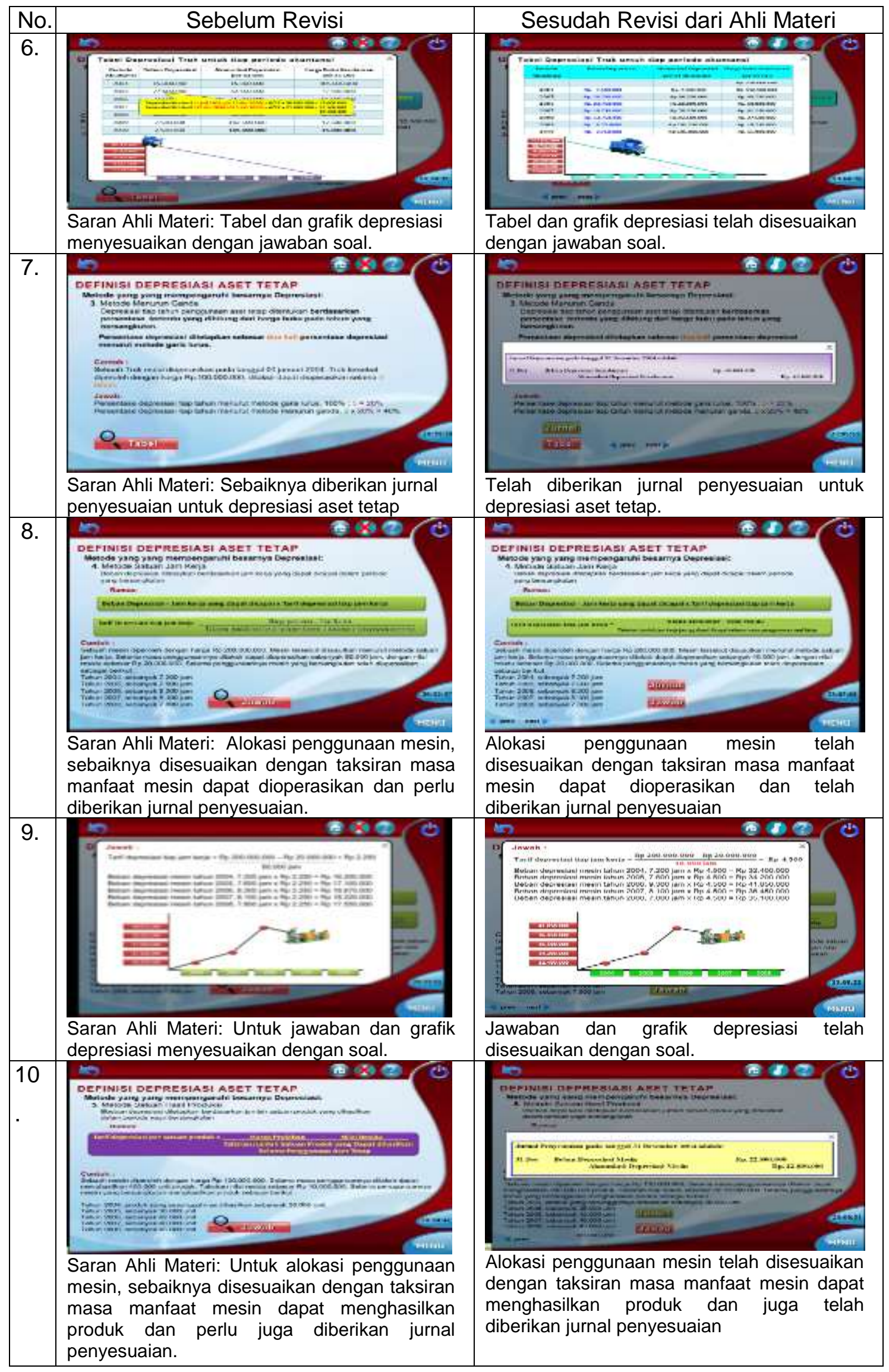




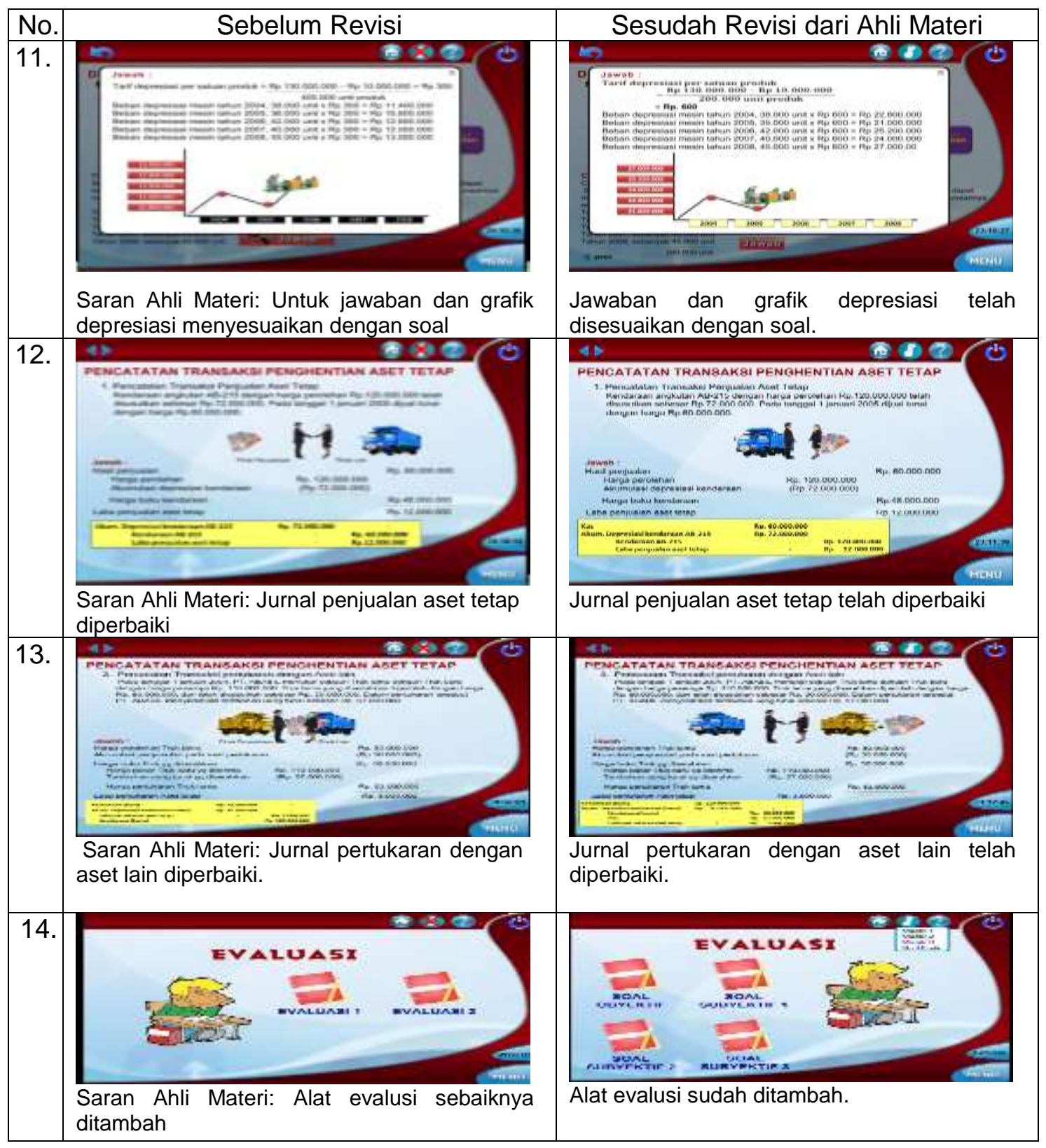

Berdasarkan tampilan bagan 1.1 dan bagan 1.2 diatas dapat disimpulkan bahwa media pembelajaran animasi interaktif yang dikembangkan oleh peneliti telah mendapatkan masukan dari ahli media dan ahli materi yang akhirnya digunakan oleh peneliti sebagai bahan pertimbangan untuk memperbaiki atau merevisi tampilan media animasi interaktif yang dikembangkan. 
Kelayakan Media Alternatif dalam Proses Pembelajaran Akuntansi Kelas XI Akuntansi Di SMK Pada Materi Pengelolaan Kartu Aset Tetap

Hasil telaah dari ahli media, ahli materi dan uji coba terbatas adalah layak tidaknya media pembelajaran interaktif yang telah dikembangkan. Untuk mengetahui kelayakan media, dilakukan penilaian pada setiap item pertanyaan dan total keseluruhan item pertanyaan yang tersedia. Hasil analisis data dalam pengembangan media diuraikan sebagai berikut:

Tabel 1.3

Rekapitulasi Hasil Validasi Media dari ahli Media

\begin{tabular}{|c|l|c|c|}
\hline No & \multicolumn{1}{|c|}{ Aspek yang dinilai } & Persentase & Kriteria Kelayakan \\
\hline 1 & Keterbacaan & $90 \%$ & Sangat Layak \\
\hline 2 & Mudah digunakan & $100 \%$ & Sangat Layak \\
\hline 3 & Kualitas tampilan/tayangan & $88,89 \%$ & Sangat Layak \\
\hline 4 & Kualitas penanganan programnya & $100 \%$ & Sangat Layak \\
\hline \multicolumn{2}{r}{ Persentase } & $\mathbf{3 7 8 , 8 9 \%}$ & - \\
\hline Rata-Rata Persentase & $\mathbf{9 4 , 7 2 \%}$ & Sangat Layak \\
\hline
\end{tabular}

Tabel 1.4

Rekapitulasi Hasil Validasi Media dari ahli Materi

\begin{tabular}{|c|c|c|c|}
\hline No & Aspek yang dinilai & Persentase & Kriteria Kelayakan \\
\hline 1 & Ketepatan & $83,33 \%$ & Sangat Layak \\
\hline 2 & Kepentingan & $100 \%$ & Sangat Layak \\
\hline 3 & Kelengkapan & $91,67 \%$ & Sangat Layak \\
\hline 4 & Keseimbangan & $83,33 \%$ & Sangat Layak \\
\hline 5 & Kesesuaian & $91,67 \%$ & Sangat Layak \\
\hline 6 & Memberikan kesempatan belajar & $83,33 \%$ & Sangat Layak \\
\hline 7 & Memberikan bantuan untuk belajar & $93,75 \%$ & Sangat Layak \\
\hline 8 & Kualitas memotivasi & $86,11 \%$ & Sangat Layak \\
\hline 9 & Fleksibelitas instruksionalnya & $100 \%$ & Sangat Layak \\
\hline \multicolumn{2}{|r|}{ Persentase } & $813,19 \%$ & - \\
\hline \multicolumn{2}{|r|}{ Rata-Rata Persentase } & $90,35 \%$ & Sangat Layak \\
\hline
\end{tabular}

Tabel 1.5

Rekapitulasi Hasil Uji Coba Terbatas (Pengguna)

\begin{tabular}{|c|c|c|c|}
\hline No & Aspek yang dinilai & Persentase & Kriteria Kelayakan \\
\hline 1 & Kemudahan dalam mempelajari materi & $96,67 \%$ & Sangat Layak \\
\hline 2 & Kesesuaian Materi & $100 \%$ & Sangat Layak \\
\hline 3 & Penyajian & $96,25 \%$ & Sangat Layak \\
\hline 4 & Ilustrasi & $100 \%$ & Sangat Layak \\
\hline 5 & Keterbacaan & $100 \%$ & Sangat Layak \\
\hline \multicolumn{2}{|r|}{$\begin{array}{c}\text { Persentase } \\
\end{array}$} & $492,92 \%$ & - \\
\hline & Rata-Rata Persentase & $98,58 \%$ & Sangat Layak \\
\hline
\end{tabular}

Tabel 1.6

Rekapitulasi Keseluruhan Hasil Uji Validasi dan Uji Coba Terbatas

\begin{tabular}{|c|l|c|c|}
\hline No & Keterangan & Persentase & Kriteria Kelayakan \\
\hline 1 & Validasi dari Ahli Media & $94,72 \%$ & Sangat Layak \\
\hline 2 & Validasi dari Ahli Materi & $90,35 \%$ & Sangat Layak \\
\hline 3 & Uji Coba Terbatas & $98,58 \%$ & Sangat Layak \\
\hline \multicolumn{2}{|c|}{ Persentase } & $\mathbf{2 8 3 , 6 5 \%}$ & - \\
\hline & Rata-Rata Persentase & $\mathbf{9 4 , 5 5 \%}$ & Sangat Layak \\
\hline
\end{tabular}


Berdasarkan Tabel 1.3, 1.4, 1.5 dan Tabel 1.6 di atas, dapat disimpulkan bahwa media animasi interaktif yang dikembangkan sudah layak digunakan sebagai media alternatif dalam proses pembelajaran akuntansi kelas XI akuntansi di sekolah menengah kejuruan pada materi pengelolaan kartu aset tetap dengan rata-rata kelayakan sebesar $94,55 \%$ atau $\geq 81 \%$ (sangat layak).

\section{Pembahasan Hasil}

Pengembangan media pembelajaran Akuntansi SMK berbasis animasi interaktif pada materi pengelolaan kartu aset tetap

Hasil pengembangan media pembelajaran animasi interaktif menggunakan model pengembangan Thiagararajan dimulai pada tahap tahap pendefinisian (Define), tahap pendesainan (Design), dan tahap pengembangan (Develop). Tahap pendefinisian yang telah dilakukan menghasilkan tiga analisis yaitu analisis masalah dasar, analasis karakteristik siswa dan analisis penyelesaian masalah. Setelah selesai tahap pendefinisian peneliti melanjutkan ke tahap pendesainan, yang mana dihasilkan tampilan draf produk media pembelajaran akuntansi berbasis animasi interaktif. Dari tahap pendesainan produk akhirnya menghasilkan produk pengembangan (tahap pengembangan) yang akhirnya divalidasi oleh ahli media (1 dosen ahli media), ahli materi berjumlah 3 orang (2 dosen dan 1 guru SMK 10 Negeri Surabaya), dan uji coba terbatas (20 siswa di SMK 10 Surabaya). Produk hasil revisi dari ahli media kemudian diserahkan kepada ahli materi untuk direvisi. Setelah direvisi oleh ahli materi kemudian diuji coba terbatas. Pelaksanaan pengembangan yang dilakukan selama penelitian berjalan dengan baik dan sesuai dengan prosedur pengembangan Thiagarajan, sehingga menghasilkan hasil produk pengembangan yang sesuai. Kesesuaian analisis masalah, analisis karakteristik siswa dan analisis penyelesaian masalah sangat penting sebagai pertimbangan untuk menentukan jenis media pembelajaran yang tepat dikembangkan.

\section{Kelayakan media alternatif dalam proses pembelajaran akuntansi kelas XI akuntansi di SMK pada materi pengelolaan kartu aset tetap}

Berdasarkan hasil penilaian pengembangan dari ahli media, bahwa tingkat kelayakan media yang dihasilkan dengan rata-rata sebesar 94,72\% (kategori sangat layak). Aspek yang dinilai adalah keterbacaan, mudah digunakan, kualitas tampilan dan kualitas penanganan programnya. Dari aspek keterbacaan yang dimulai dari pemilihan model, ukuran, warna teks, kejelasan font dan huruf, penggunaan bahasa, tombol media, dan pada pemilihan musik pengiring semua dinilai dengan kategori 
sangat layak dan layak. Begitu pula dengan aspek mudah digunakan, kualitas tampilan dan kualitas penanganan programnya dengan kategori sangat layak.Berdasarkan hasil penilaian pengembangan dari ahli materi, bahwa tingkat kelayakan media yang dihasilkan dari aspek ketepatan, kepentingan, kelengkapan, keseimbangan, kesesuaian, memberikan kesempatan belajar, memberikan bantuan untuk belajar, kualitas memotivasi, dan fleksibilitas instruksionalnya dengan total rata-rata sebesar 90, 35\% (kategori sangat layak).Berdasarkan pada hasil uji coba terbatas yang diuji cobakan kepada 20 siswa SMK Negeri 10 Surabaya, bahwa tingkat kelayakan yang dihasilkan dari aspek kemudahan dalam mempelajari materi, kesesuaian materi, penyajian, ilustrasi dan keterbacaan dengan rata-rata sebesar 98,58\% (kategori sangat layak). Rata-rata hasil uji coba dari ahli media, ahli materi dan uji coba terbatas yaitu siswa diperoleh skor keseluruhan sebesar 94,55\%, sehingga dapat disimpulkan bahwa media yang telah dikembangkan layak digunakan sebagai media alternative untuk materi pengelolaan kartu aset tetap. Kriteria kelayakan dengan kategori sangat layak ini mengindikasikan bahwa media pembelajaran yang telah dikembangkan pada akhirnya bisa ditindaklajuti untuk diterapkan pada proses pembelajaran di kelas sebagai media pembelajaran alternative untuk materi aset tetap SMK.

\section{KESIMPULAN}

Berdasarkan hasil penelitian dan pembahasan hasil penelitian, dapat disimpulkan bahwa:

1. Pengembangan media pembelajaran akuntansi berbasis animasi interaktif ini menggunakan model pengembangan menurut Thiagarajan yaitu model 4D (four $D$ Models) yang terdiri dari: tahap pendefinisian (Define), tahap pendesainan (Design), tahap pengembangan (Develop), dan tahap penyebaran (Disseminate). Penelitian ini hanya sampai pada tahap pengembangan, tahap keempat tidak dilakukan karena keterbatasan waktu, tenaga dan biaya. Proses pengembangan media animasi interaktif harus melalui tahapan telaah media oleh ahli media dan ahli materi, revisi media, uji validasi media oleh ahli media dan ahli materi, uji coba terbatas kepada 20 siswa kelas XI Akuntansi di Sekolah Menengah Kejuruan.

2. Media pembelajaran akuntansi berbasis animasi interaktif menggunakan program macromedia flash yang dikembangkan ini layak digunakan sebagai media alternatif dalam proses pembelajaran akuntansi di sekolah menengah kejuruan pada materi pengelolaan kartu aset tetap dengan kriteria kelayakan $\geq 61 \%$ yaitu sebesar $94,55 \%$ (sangat layak). 


\section{SARAN}

Berdasarkan hasil analisis data dan kesimpulan di atas, dapat dikemukakan beberapa saran sebagai berikut:

1. Media animasi interaktif yang dikembangkan menggunakan program macromedia flash ini cocok untuk diterapkan dengan menggunakan model pembelajaran langsung, karena pada media ini tidak disertai dengan suara narator (melainkan musik instrument).

2. Penggunaan media animasi interaktif ini diperlukan spesifikasi komputer sebagai berikut: 1) windows 98, windows 2010 profesional, windows XP professional, windows seven 2) minimal 256 MB of RAM 3) minimal 32-64 MB or higher of VGA 4) intel Pentium-class or compatible processor rated at $800 \mathrm{MHz}$ or higher 5) $C D$ Room/ DVD-Room drive.

3. Pengembangan media pembelajaran akuntansi berbasis animasi interaktif pada materi pengelolaan kartu aset tetap ini hanya sampai pada tahap pengembangan (develop). Oleh karena itu, perlu dilakukan lebih lanjut pada tahap penyebaran (dessiminate).

4. Penelitian pengembangan media pembelajaran akuntansi berbasis animasi interaktif ini hanya sebatas menguji kelayakan media yang di tentukan berdasarkan penilaian angket dari validasi ahli media dan ahli materi serta pendapat siswa. Oleh karena itu, perlu dilakukan penelitian lebih lanjut tentang kelayakan media sampai dengan hasil belajar yang dicapai siswa setelah menggunakan media yang dikembangkan.

5. Penelitian pengembangan media pembelajaran akuntansi berbasis animasi interaktif ini hanya terbatas pada materi pengelolaan kartu aset tetap. Oleh karena itu, perlu dilakukan pengembangan media lebih lanjut pada materi akuntansi yang lainnya.

\section{DAFTAR PUSTAKA}

Agustina, Melani. 2011. Pengembangan Media Interaktif Berbasis Komputer Pada Materi Pokok Asam Dan Basa. (Skripsi tidak dipublikasikan). Surabaya: Jurusan Kimia. UNESA.

Arsyad, Azhar. 2007. Media Pembelajaran. Jakarta: PT. Raja Grafindo Persada.

Aula, Khussotul. 2011. Pengembangan Media Pembelajaran Interaktif Berbasis Komputer Pada Sub Pokok Bahasan Jurnal Penyesuaian Perusahaan Jasa. (Skripsi tidak dipublikasikan). Surabaya: Jurusan Pendidikan Ekonomi Akuntansi. UNESA.

Riduwan. 2010. Skala Pengukuran Variabel-Variabel Penelitian. Bandung: Alfabeta.

Saputro, Irfan. 2011. Pengembangan media pembelajaran interaktif berbasis komputer pada materi pokok termokimia bilingual kelas XI IPS di Rintisan SMA Bertaraf 
Internasional. (Skripsi tidak dipublikasikan). Surabaya: Jurusan Kimia. UNESA.

Susilana dan Riyana. 2007. Media Pembelajaran: Hakikat, Pengembangan, Pemanfaatan, dan Penilaian. Bandung: CV Wacana Prima.

Trianto. 2009. Mendesain Model Pembelajaran Inovatif-Progresif: Konsep, Landasan, dan Implementasinya Pada Kurikulum Tingkat Satuan Pendidikan (KTSP). Jakarta: Kencana Prenada Media Group.

Tim Penyusun. 2006. Panduan Penulisan dan Penilaian Skripsi Universitas Negeri Surabaya. Surabaya: University Press.

2009. Animasi. (Online). (http://id.wikipedia.org/wiki/Animasi, diakses 07 Maret 2012). 